Revista Brasileira de Agricultura Irrigada v.8, no. 2, p. 114 - 126, 2014

ISSN 1982-7679 (On-line)

Fortaleza, CE, INOVAGRI - http://www.inovagri.org.br

DOI: $10.7127 /$ rbai.v8n200225

Protocolo 225/14 - 29/09/2013 Aprovado em 10/03/2014

\title{
COMPARISON OF METHODS FOR ESTIMATING REFERENCE EVAPOTRANSPIRATION IN TWO LOCATIONS OF ESPIRITO SANTO
}

\author{
Joabe Martins de Souza ${ }^{1}$, Lucas Rosa Pereira ${ }^{2}$, Anatan da Matta Rafael ${ }^{2}$, Leandro Dias da \\ Silva ${ }^{3}$, Edvaldo Fialho dos Reis ${ }^{4}$, Robson Bonomo ${ }^{5}$
}

\begin{abstract}
The determination or estimate of reference evapotranspiration (ETo) is of great importance to determine the optimal supply of water to a culture. The Penman-Monteith (FAO 56) is recommended as the standard for estimating ETo, when the absence of weighing lysimeter. In the present study it was compared five methods for estimating the ETo, with the Penman-Monteith method in the dry and humid season of the year 2012, in two localities of the state of Espirito Santo, in the north (Nova Venecia) and the mountainous region (Santa Teresa). To assess the adjustment of the methods for estimating the ETo with the Penman-Monteith (FAO-56) it was used the values of the coefficients of determination $\left(\mathrm{R}^{2}\right)$ and correlation (r), the Standard Error of Estimate (SEE), Standard Error of Estimate Adjusted (SEEa), Standard Error of Estimate Adjusted by Origin (SEEao) for methods that showed better assessment, and the agreement indexes (d) and performance (c). The methods Priestley-Taylor, Hargreaves \& Samani and Blaney \& Criddle, showed better assessment when compared with the Penman-Monteith method to Santa Teresa-ES, for the two seasons studied, the first two overestimated and the Blaney \& Criddle underestimated the ETo values. The methods of Camargo and Makkink, obtained lower classification of estimate of ETo. To Nova Venecia-ES in the rainy season the methods Priestley-Taylor, Hargreaves \& Samani and Blaney \& Criddle, obtained the best results, but the first two overestimated and the last underestimated, for the dry season only the methods PriestleyTaylor, Hargreaves \& Samani showed better assessment, overestimating the values of ETo. In both seasons the methods of Camargo and Makkink obtained lower classification, as well Blaney \& Criddle for the dry season. Hargreaves \& Samani and Priestley-Taylor are
\end{abstract}

\footnotetext{
${ }^{1}$ Eng. Agrônomo, Doutorando em Produção Vegetal, Centro de Ciências Agrárias da Universidade Federal do Espírito Santo, CCA/UFES, Alto Universitário, Alegre - ES, Brasil, Fone: (27)9-9273-3947 e-mail: joabenv@gmail.com

${ }^{2}$ Tecnólogo em Cafeicultura, Mestrando em Produção Vegetal, Centro de Ciências Agrárias da Universidade Federal do Espírito Santo, CCA/UFES, Alegre - ES, Brasil

${ }^{3}$ Eng. Agrônomo, Doutorando em Produção Vegetal, Centro de Ciências Agrárias da Universidade Federal do Espírito Santo, CCA/UFES, Alto Universitário, Alegre - ES, Brasil,

${ }^{4}$ Eng. Agrícola, D.Sc. Professor do Departamento de Engenharia Rural, Centro de Ciências Agrárias da Universidade Federal do Espírito Santo, CCA/UFES, Alegre - ES, Brasil

${ }^{5}$ Eng. Agrônomo, D.Sc. Professor do Departamento de Ciências Agrais e Biológicas, Centro Universitário Norte do Espírito Santo, Universidade Federal do Espírito Santo, CEUNES/UFES, São Mateus - ES, Brasil
} 
indicated for both locations, and Blaney \& Criddle, except in the dry season of Nova Venecia-ES.

Keywords: water requirements, Penman-Monteith (FAO-56), weather variables

\title{
COMPARAÇÃO ENTRE MÉTODOS DE ESTIMATIVA DA EVAPOTRANSPIRAÇÃO DE REFERÊNCIA EM DUAS LOCALIDADES DO ESPÍRITO SANTO
}

\begin{abstract}
RESUMO
A determinação ou estimativa da evapotranspiração de referência (ETo) é de grande importância para determinar o suprimento de água ideal para uma cultura. $\mathrm{O}$ método de Penman-Monteith (FAO 56) é recomendado como padrão para estimativa da ETo, quando da ausência de lísimetro de pesagem. No presente trabalho foi realizada a comparação entre cinco métodos de estimativa da ETo, com o método de Penman-Monteith, no período seco e úmido do ano de 2012, em duas localidades do Espírito Santo, no norte (Nova Venécia) e na região serrana (Santa Teresa). Para avaliar o ajuste dos métodos de estimativa da ETo com o método de Penman-Monteith (FAO-56) utilizou-se os valores dos coeficientes de determinação $\left(\mathrm{R}^{2}\right)$ e de correlação (r), do Erro Padrão da Estimativa (EPE), Erro Padrão da Estimativa Ajustado (EPEa), Erro Padrão da Estimativa Ajustado pela origem (EPEao) para os métodos que apresentaram melhor avaliação, e os índices de concordância $(d)$ e desempenho (c). Os métodos Priestley-Taylor, Hargreaves \& Samani e Blaney \& Criddle, apresentaram melhor avaliação quando comparados com o método de Penman-Monteith para Santa Teresa-ES, para os dois períodos estudados, os dois primeiros superestimaram e o Blaney \& Criddle subestimou os valores de ETo . Os métodos de Camargo e Makkink, obtiveram classificação inferior na estimativa da ETo. Para Nova Venécia-ES no período chuvoso os métodos Priestley-Taylor, Hargreaves \& Samani e Blaney \& Criddle, obtiveram os melhores resultados sendo que os dois primeiros superestimaram e o último subestimou, para o período seco apenas os métodos PriestleyTaylor, Hargreaves \& Samani apresentaram melhor avaliação, superestimando os valores de ETo. Nos dois períodos os métodos de Camargo e Makkink obtiveram classificação inferior, como também Blaney \& Criddle para o período seco. Hargreaves \& Samani e Priestley-Taylor são indicados para ambas as localidades, e Blaney \& Criddle, exceto no período seco de Nova Venécia-ES.
\end{abstract}

Palavras-chave: necessidade hídrica, Penman-Monteith, variáveis climáticas

\section{INTRODUCTION}

For irrigated agriculture, irrigation is considered essential, especially in arid, semiarid and others regions where there is an irregular rainfall distribution. However, for good yields, the practice of irrigation has to be conducted to determine how much water to apply and the appropriate time in order to 
supply the water requirement of the crop. This amount to be applied through irrigation has as main parameter the knowledge of evapotranspiration (RODRIGUES et at., 2013).

The reference evapotranspiration (ETo) is one of the main components of the water balance, and very useful in climatology, or in climate classifications or for quantification of regional water availability as well in the water management in irrigation systems (SOUZA et al., 2011a). According to Gonçalves et al. (2009) the point that requires more care is irrigation management, the irrigated crop conduction defining accurately the water requirements of the crop and the depth and the moment the most appropriate irrigation.

The evaporation can be defined as the amount of water evaporated and transpired from a vegetated surface for a certain period of time (ORTEGA-FARIAS et al., 2009), but the reference evapotranspiration (ETo) can be defined as the amount of water transpired in a large area, with grassy cover of uniform height, between 8 and $15 \mathrm{~cm}$, actively growing, with the soil completely shading and without water deficit (AL-GHOBARI, 2000), and can be expressed as total, average, daily and hours values, in volume per unit of area or depth of water per predetermined period.

The Penman-Monteith-FAO method to estimate of reference evapotranspiration is considered the standard reference method (ALLEN et al., 1998). According to Oliveira et al. (2010) the ETo relates to the effect of atmospheric demand on water requirements of crops, being estimated through meteorological variables. It involves, however, a lot of meteorological variables that are not always available to farmers, especially in small areas, that usually have only records of air temperature. On the other side, the empirical methods, originating from the correlation of ETo measured under standardized conditions with meteorological elements measured in these same places, require fewer variables and may present with good applicability (ARAUJO et al., 2012).

ETo is, therefore, of fundamental significance for the design of systems and for the management of irrigation water, which requires the adoption of studies, assessments and adjustments to its correct use. However, the adoption of the simplest methods is necessary and demonstrably effective for estimate of ETo and can contribute to the implementation of practices for irrigation management.

Thus, the objective of this study was to compare five methods for estimating the ETo with the Penman-Monteith method, in dry and humid seasons of the year of 2012 at two localities in the state of Espirito Santo, in the north (Nova Venecia) and mountainous region (Santa Teresa). 


\section{MATERIAL AND METHODS}

The work was carried out at two localities of the State of Espírito Santo, in Nova Venecia city, north of state (latitude $18^{\circ} 41^{\prime} \mathrm{S}$, longitude $40^{\circ} 23^{\prime} \mathrm{W}$ and altitude of $154.0 \mathrm{~m}$ ), and Santa Teresa city, mountainous region of the state (latitude $19^{\circ} 59^{\prime} \mathrm{S}$, longitude $40^{\circ} 34^{\prime} \mathrm{W}$ and altitude of $655.0 \mathrm{~m})$.

The characteristic climate of Nova Venecia-ES, according to the classification of Köeppen, is type Aw, tropical with a dry season, with temperatures ranging between 11.8 and 18 ${ }^{\circ} \mathrm{C}$ in the coldest month, and between 30.7 and $340{ }^{\circ} \mathrm{C}$ in the hottest month, annual average temperature of $24{ }^{\circ} \mathrm{C}$. The average annual rainfall is $1,234 \mathrm{~mm}$, with rainy season between the months of October and February, and characteristically dry season between the months of March and September.

The city of Santa Teresa-ES has humid temperate climate with dry winter and hot summer, Cwa, according to the Köeppen classification. It contains mild temperatures throughout most of the year, with maximum average temperatures of $29.3{ }^{\circ} \mathrm{C}$, average minimum temperatures of $10.6{ }^{\circ} \mathrm{C}$, and average annual temperature of $19.9{ }^{\circ} \mathrm{C}$. The rainfall index is $1,332 \mathrm{~mm}$, with the rainiest months from November to April, and the least rainy months from May to August.
The coffee growing and dairy cattle farming are the main activities of the primary sector of Nova Venecia city. For Santa Teresa, cattle ranching activity, vegetable crops and coffee growing are the main agricultural activities in this region, and the cultivation of fine table grape has also been an alternative to diversify the agricultural activity of the city (BUSATO; BUSATO, 2011).

The data relating to climatic variables were obtained through an automatic INMET station of INMET, located in the cities of Nova Venecia and Santa Teresa-ES. The calculations of estimate of ETo was performed by using the methods Penman-Montheith (ALLEN et al., 1998) (1), Hargreaves \& Samani (1985), Camargo (1971), Makkink (1957), Priestley Taylor (1972) and Blaney \& Criddle (ALLEN; PRUITT, 1986).

$$
\text { ETo }=\frac{0,408 \Delta(\mathrm{Rn}-\mathrm{G})+\gamma \frac{900}{\mathrm{~T}+2 \pi \mathrm{s}} \mathrm{u} \mathrm{n}\left(e_{\mathrm{g}}-e_{\mathrm{d}}\right)}{\Delta+\gamma\left(1+0,34 \mathrm{u}_{\mathrm{n}}\right)}
$$

Wherein:

ETo - reference evapotranspiration $\left(m m . d^{-1}\right), R n$ - net radiation at the surface $\left(M J \cdot m^{-2} \cdot d^{-1}\right), G$ soil heat flux $\left(\mathrm{MJ} \cdot \mathrm{m}^{-2} \cdot \mathrm{d}^{-1}\right), \mathrm{T}$ - air temperature $\left({ }^{\circ} \mathrm{C}\right) ; \mathrm{u}_{2}$ - wind speed at $2.0 \mathrm{~m}$ height $\left(\mathrm{m} \mathrm{s}^{-1}\right) ;\left(\mathrm{e}_{\mathrm{s}}{ }^{-}\right.$ $\left.e_{d}\right)$ - vapor pressure deficit $(\mathrm{kPa}), \Delta$ - the slope of the curve saturation vapor pressure $\left(\mathrm{kPa} . \mathrm{C}^{-1}\right)$, $\gamma$ - psychrometric constant $\left(\mathrm{kPa} . \mathrm{C}^{-1}\right)$. 
The daily ETo values were divided into dry season and humid season, according to the rainfall characteristics of the region of Nova Venecia and Santa Teresa-ES, the region of Nova Venecia has humid period between October and February and dry period in the remaining months, and Santa Teresa-ES has humid period from October to April, and the dry period in the remaining months of the year, according to Incaper (2011).

To compare the values of ETo between Penman-Montheith with the others methods, it was used the criteria proposed by Jensen et al. (1990), which are the standard error of estimate (SEE) (2) and the standard error of estimate adjusted (SEEa) (3), coefficient of adjustment of the complete linear equations, and also their coefficients of determination $\left(\mathrm{R}^{2}\right)$ and standard error of estimate adjusted by origin (SEEao) to the methods that showed better assessment. Methodology similar to that used to compare methods for estimate of ETo in study by Chagas et al. (2013).

$$
\begin{gathered}
\mathrm{SEE}=\left(\frac{\Sigma\left(Y_{i}-Y_{m}\right)^{\mathrm{Z}}}{n-1}\right)^{0,5} \\
\mathrm{SEEa}=\left(\frac{\Sigma\left(Y_{i c}-Y_{m}\right)^{2}}{n-1}\right)^{0,5}
\end{gathered}
$$

wherein:

$Y_{i}$ - evapotranspiration estimated by the method $\left(\mathrm{mm} . \mathrm{d}^{-1}\right) ; \mathrm{Y}_{\mathrm{m}}$ - evapotranspiration estimated by the standard method $\left(\mathrm{mm} . \mathrm{d}^{-1}\right) ; \mathrm{Y}_{\mathrm{ic}}$ - estimated using evapotranspiration, adjusted by coefficients of linear regression $\left(\mathrm{mm} \cdot \mathrm{d}^{-1}\right)$; and $\mathrm{n}$ - total number of observations.

It also was tested in the correlation of estimated values of ETo parameters related to precision, the correlation coefficient (r) (4), the accuracy (Willmott index "d") (5), described by Willmott et al. (1985) and their values range between zero (no concordance) and 1 (perfect concordance) and performance (index "c") (6), described in Camargo and Sentelhas (1997).

$$
\mathrm{r}=\sqrt{R^{2}}
$$

wherein:

$\mathrm{r}$ - correlation coefficient, $\mathrm{R}^{2}$ - coefficient of determination.

$$
d=1-\left[\frac{\mathbb{z}\left(p_{i}-o_{i}\right)^{2}}{\mathbb{z}\left[\left(p_{i}-o\right]+\left[o_{i}-o \mid\right)^{2}\right.}\right]
$$

wherein:

$\mathrm{P}_{\mathrm{i}}$ - Estimated value; $\mathrm{O}_{\mathrm{i}}$ - observed value, and $\mathrm{O}$ - average of the observed values.

$$
c=\mathrm{r} \cdot d
$$

wherein:

$\mathrm{r}$ - correlation coefficient, $\mathrm{d}$ - index Willmott.

For interpretation of the methods of estimate of ETo using the performance index "c", it was used the criteria proposed by Camargo e Sentelhas (1997), which are in Table 1. 
Table 1. Values of "c" interpretive criteria for the performance of estimating ETo.

\begin{tabular}{cc}
\hline Values de "c" & Performance \\
\hline$>0,85$ & Excellent \\
$0,76-0,85$ & Very good \\
$0,66-0,75$ & Good \\
$0,61-0,65$ & Median \\
$0,51-0,60$ & Tolerable \\
$0,40-0,50$ & Poor \\
$\leq 0,40$ & Very poor
\end{tabular}

\section{RESULTS AND DISCUSSION}

In Table 2 is showed the analysis of complete regression between the estimate of ETo values, as well the coefficients of determination $\left(\mathrm{R}^{2}\right)$ and the precision parameters for the humid period of the two cities. It is observed that the Hargreaves \& Samani, Priestley-Taylor and Blaney \& Criddle methods were those with the best precision parameters, also better coefficient of determination and also the standard error of estimate (SEE) and the standard error of estimated adjusted (SEEa) close to zero, a result more significant for the Priestley-Taylor method, for both locations during the humid season.

These results led these methods to show classification from good to excellent, for the humid season, and the Priestley-Taylor method showed to be excellent for estimate of ETo for the two cities studied, but the methods of Hargreaves \& Samani, Blaney \& Criddle had a very good performance for Nova Venecia and excellent and good, respectively, for Santa Teresa.

The methods of Camargo and Makkink showed lower parameters of precision to estimate of ETo in these cities, also with low coefficients of determination for the regression equations generated in relation to the PenmanMontheith method, consequently obtained classification from very poor to poor for estimates of ETo, for the humid period in these locations.

According to Borges Junior et al. (2012) and Souza et al. (2011b) it is possible that during the rainiest period of the year the values of "c" for the method of Camargo show higher values, considering that this model performance tends to be better under cloudier conditions, fact not observed in this study, Araújo et al. (2012) found a bad performance for the method of Camargo in Roraima, noting that the value observed in their work reflects the meteorological conditions of the period of the year when there is a reduction in the occurrence of rainfall and, consequently, a higher demand for use of irrigation. 
Table 2. Equation parameters $(\beta 0, \beta 1)$, coefficient of determination $\left(\mathrm{R}^{2}\right)$, standard error of estimate (SEE), standard error of adjusted estimate (SEEa), correlation coefficient ( $r$ ), index of agreement (d), the confidence index performance or (c), during the humid period in the two study sites.

\begin{tabular}{|c|c|c|c|c|c|c|c|c|}
\hline \multirow{2}{*}{$\begin{array}{l}\text { Penman- } \\
\text { Montheith }\end{array}$} & \multicolumn{8}{|c|}{ Nova Venecia - Period Humid } \\
\hline & $\beta 1$ & $\mathrm{R}^{2}$ & SEE & SEEa & $\mathrm{r}$ & $d$ & $\mathrm{c}$ & Performance \\
\hline $\begin{array}{c}\text { Hargreaves } \\
\text { \& Samani }\end{array}$ & $2,13120,6952$ & 0,86 & 0,90 & 0,81 & 0,93 & 0,90 & 0,83 & Very good \\
\hline Camargo & $3,62900,0963$ & 0,42 & 1,99 & 1,45 & 0,65 & 0,49 & 0,32 & Very poor \\
\hline Makkink & $5,25150,0970$ & 0,65 & 1,61 & 1,61 & 0,81 & 0,51 & 0,41 & Poor \\
\hline $\begin{array}{c}\text { Priestley- } \\
\text { Taylor }\end{array}$ & $0,27300,9729$ & 0,96 & 0,30 & 1,15 & 0,98 & 1,0 & 0,98 & Excellent \\
\hline $\begin{array}{c}\text { Blaney \& } \\
\text { Criddle }\end{array}$ & $1,80880,5148$ & 0,91 & 0,88 & 0,86 & 0,95 & 0,85 & 0,81 & Very good \\
\hline \multirow{2}{*}{$\begin{array}{l}\text { Penman- } \\
\text { Montheith }\end{array}$} & \multicolumn{8}{|c|}{ Santa Teresa - Period Humid } \\
\hline & $\beta 0$ & $\mathrm{R}^{2}$ & SEE & SEEa & $r$ & d & $\mathrm{c}$ & Performance \\
\hline $\begin{array}{c}\text { Hargreaves } \\
\text { \& Samani }\end{array}$ & $1,66920,6388$ & 0,86 & 0,72 & 0,63 & 0,93 & 0,94 & 0,87 & Excellent \\
\hline Camargo & $3,48200,1007$ & 0,10 & 1,35 & 1,27 & 0,32 & 0,33 & 0,10 & Very poor \\
\hline Makkink & $4,33240,2009$ & 0,26 & 1,90 & 1,84 & 0,51 & 0,58 & 0,30 & Very poor \\
\hline $\begin{array}{l}\text { Priestley- } \\
\text { Taylor }\end{array}$ & $0,35451,0981$ & 0,96 & 0,78 & 0,14 & 0,98 & 1,0 & 0,98 & Excellent \\
\hline $\begin{array}{l}\text { Blaney \& } \\
\text { Criddle }\end{array}$ & $1,01850,4597$ & 0,84 & 1,21 & 1,19 & 0,92 & 0,76 & 0,70 & Good \\
\hline
\end{tabular}

Analyzing the forced regression through the origin and the standard error of estimate adjusted for origin (SEEao) of the methods which showed better performance rating, it can be noted in Figure 1, that for the humid season in both cities, the methods of Hargreaves \& Samani and Priestley-Taylor overestimated the ETo in relation to Penman-Montheith in $10.70 \%$ and $2.57 \%$ respectively for Nova Venecia-ES and $4.47 \%$ and $18.43 \%$ for Santa Teresa-ES, when the Priestley-Taylor method showed higher coefficient of determination for both cities.

According to Jensen et al. (1990) methods which are based on air temperature and radiation, as is the case of Hargreaves \& Samani, tend to overestimate ETo $15-20 \%$ in humid climates, contrary to the values found in this work.

The Blaney \& Criddle method underestimated the reference evapotranspiration in $13.57 \%$ and $29.26 \%$ for Nova Venecia and Santa Teresa respectively. It was also noted that the standard error of estimate was practically low for all methods, except for the method of Blaney \& Criddle, showing values of SEEao of 0.04, 0.07 and $0.68 \mathrm{~mm} \mathrm{~d}^{-1}$ for Hargreaves \& Samani, Priestley-Taylor and Blaney \& Criddle respectively to Nova Venecia, and $0.17,0.71$ and $1.13 \mathrm{~mm} \mathrm{~d}^{-1}$ to Santa Teresa.

For the climatic conditions of the cities of Sooretama, Cachoeiro de Itapemirim, Venda Nova do Imigrante, located respectively in the northern, southern and mountainous of state of the Espirito Santo in rainy dry period, Bragança et al. (2010) highlighted as the best methods in order Penman (48) Original, FAO 24 Pn Mod, FAO 24 BC, Priestley-Taylor, Turc, Makkink and Hargreaves \& Samani. 

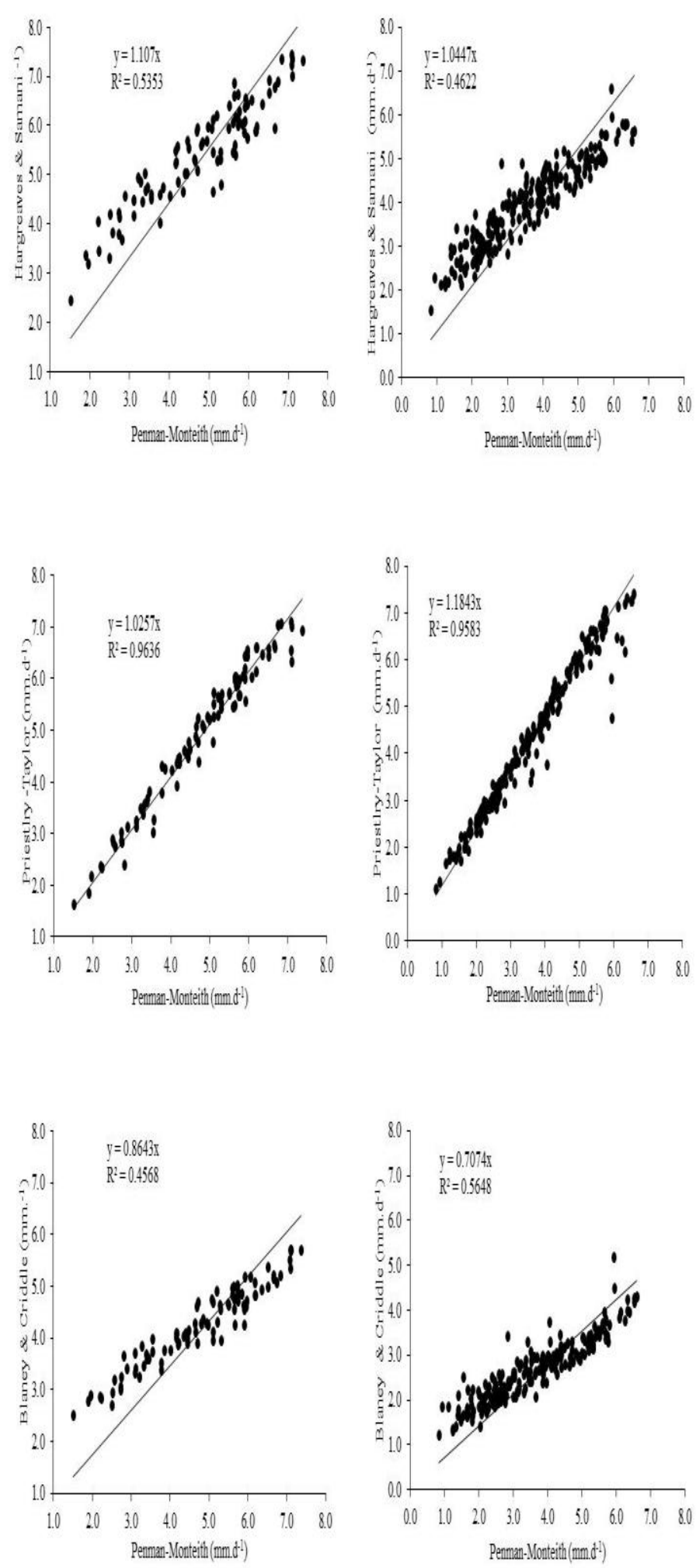

Figure 1. Linear regression between daily values of reference evapotranspiration (ETo) for the wet period, forced through the origin, estimated by the PenmanMonteith in relation to the Hargreaves \& Samani, Priestley-Taylor, Blaney \& Criddle FAO-24 for Location of Nova Venecia-ES (left) and Santa TeresaES (right).
For the dry period in Nova Venecia, the Hargreaves \& Samani, Priestley-Taylor methods, showed better results for all precision parameters studied, thus obtaining classification of performance good and excellent for estimate of ETo in this location. The Priestley-Taylor method was the one that had better performance in the humid period. But the methods of Camargo and Makkink had lower performance in the humid period, same result found by Blaney \& Criddle, different from that found for the humid season in Nova Venecia (Table 3). Cavalcante Junior et al. (2011), working in the northeast semiarid found that, in general, the methods tested showed an improvement in the accuracy of the estimate, from the dry to the humid season, once that none of them was considered "very poor" in the first semester studied, contrary result the dry period for Nova Venecia in this study in relation to the method of Blaney \& Criddle.

Silva et al. (2011) working under climatic conditions of Uberlândia found that the Priestley-Taylor method was more accurate and reliable compared to other methods. When it only has data for air temperature, the method of Thornthwaite or Hargreaves \& Samani can be used with good reliability, showing that irrigation management requires, in addition to appropriate methods and technology, studies of specific water consumption for each crop in different times, places and stages of 
development. An alternative for the efficient management of irrigation systems is by estimating reference evapotranspiration (ETo).

The city of Santa Teresa-ES, in the dry period showed performance results of methods of estimate of ETo, similar to the humid season, for all the studied parameters.

Table 3. Equation parameters $(\beta 0, \quad \beta 1)$, coefficient of determination $\left(\mathrm{R}^{2}\right)$, standard error of estimate (SEE), standard error of adjusted estimate (SEEa), correlation coefficient (r), index of agreement (d), the confidence index performance or (c), during the dry period in the two study sites.

\begin{tabular}{|c|c|c|c|c|c|c|c|c|c|}
\hline \multirow{2}{*}{$\begin{array}{l}\text { Penman- } \\
\text { Montheith }\end{array}$} & \multicolumn{9}{|c|}{ Nova Venecia - Period Dry } \\
\hline & $\beta 0$ & $\beta 1$ & $\mathrm{R}^{2}$ & SEE & SEEa & $\mathrm{r}$ & $\mathrm{d}$ & $\mathrm{c}$ & Performance \\
\hline $\begin{array}{l}\text { Hargreaves } \\
\text { \& Samani }\end{array}$ & 1,4736 & 0,6794 & 0,51 & 0,37 & 0,17 & 0,71 & 0,96 & 0,69 & Good \\
\hline Camargo & 1,6903 & 0,3002 & 0,31 & 0,78 & 0,97 & 0,56 & 0,57 & 0,32 & Very poor \\
\hline Makkink & 2,6631 & 0,4032 & 0,36 & 0,44 & 0,33 & 0,60 & 0,81 & 0,49 & poor \\
\hline $\begin{array}{l}\text { Priestley- } \\
\text { Taylor }\end{array}$ & $-0,8563$ & 1,1649 & 0,89 & 0,21 & 0,10 & 0,95 & 0,99 & 0,94 & Excellent \\
\hline $\begin{array}{c}\text { Blaney \& } \\
\text { Criddle }\end{array}$ & 2,3436 & 0,2950 & 0,26 & 0,50 & 0,65 & 0,51 & 0,53 & 0,27 & Very poor \\
\hline \multirow{2}{*}{$\begin{array}{l}\text { Penman- } \\
\text { Montheith }\end{array}$} & \multicolumn{9}{|c|}{ Santa Teresa - Period Dry } \\
\hline & $\beta 0$ & $\beta 1$ & $\mathrm{R}^{2}$ & SEE & SEEa & $\mathrm{r}$ & d & $\mathrm{c}$ & Performance \\
\hline $\begin{array}{c}\text { Hargreaves } \\
\text { \& Samani }\end{array}$ & 0,8151 & 0,6854 & 0,80 & 0,43 & 0,30 & 0,89 & 0,96 & 0,86 & Excellent \\
\hline Camargo & 1,3694 & 0,1864 & 0,30 & 0,88 & 0,84 & 0,55 & 0,56 & 0,31 & Very poor \\
\hline Makkink & 2,7305 & 0,2899 & 0,29 & 1,38 & 1,32 & 0,54 & 0,59 & 0,32 & Very poor \\
\hline $\begin{array}{l}\text { Priestley- } \\
\text { Taylor }\end{array}$ & 0,4515 & 0,9416 & 0,93 & 0,39 & 0,33 & 0,96 & 0,97 & 0,94 & Excellent \\
\hline $\begin{array}{c}\text { Blaney \& } \\
\text { Criddle }\end{array}$ & 0,5457 & 0,5666 & 0,85 & 0,60 & 0,57 & 0,92 & 0,82 & 0,76 & Very good \\
\hline
\end{tabular}

It is noted in Figure 2 that in the dry season to Nova Venecia, the Priestley-Taylor method underestimated $(2.98 \%)$ the ETo compared to Penman-Montheith, different result was found for the humid period that overestimated $(2.57 \%)$, although there was a decrease in the coefficient of determination and an increase of SEEao compared to the humid season. The method of Hargreaves \& Samani, in spite of the low overestimation $(1.45 \%)$ of ETo in that period and locality, showed marked dispersion, what can be evidenced by the very low coefficient of determination $\left(\mathrm{R}^{2}=0.37\right)$. On the other side the method Blaney \& Criddle underestimated $17.20 \%$ the ETo.

Reis et al. (2007) working with weather conditions in the North, South and mountainous regions of state of Espirito Santo found, due to the indices and parameters studied, during the dry season the best methods, in order, were: Penman 48 Original, Priestley-Taylor, FAO24 Penman modified, FAO24 Blaney \& Criddle and Turc, FAO24 Radiation and Makkink.

The standard error of estimate adjusted for origin (SEEao) for both locations showed near to zero, for Santa Teresa there was an increase in the coefficient of determination for the methods of Hargreaves \& Samani and Blaney \& 
Criddle, and decrease in the standard error of the estimate adjusted for origin, also showed an overestimation and of $0.25 \%$ and underestimation of $22.11 \%$ respectively, and this percentage was lower than that found in the humid season.

Santos et al. (2010), França Neto et al. (2011) and Araújo et al. (2012) found that the method of Hargreaves \& Samani showed closer to the method of Penman-Monteith-FAO to estimate reference evapotranspiration, but the method of Blaney \& Criddle underestimates the ETo values in different climatic conditions, especially in periods of high evapotranspiration demand, similar results found in this work, obtaining lower rating for the dry period studied in both regions.

Gardiman Junior et al. (2012) found that the methods, Thornthwaite (c =0.28), Camargo $(c=0.27)$ and Camargo Simplified $(c=0.36)$, were classified as very poor performance, while Priestley-Taylor $(\mathrm{c}=0.48)$ was rated as poor, similar results found in this study in relation to the method of Camargo. For the SEE the highest value was of Priestley-taylor (3.529 $\mathrm{mm} \mathrm{day}^{-1}$ ) followed by the method of Camargo $(1.366 \mathrm{~mm}$ day $\left.^{-1}\right)$.
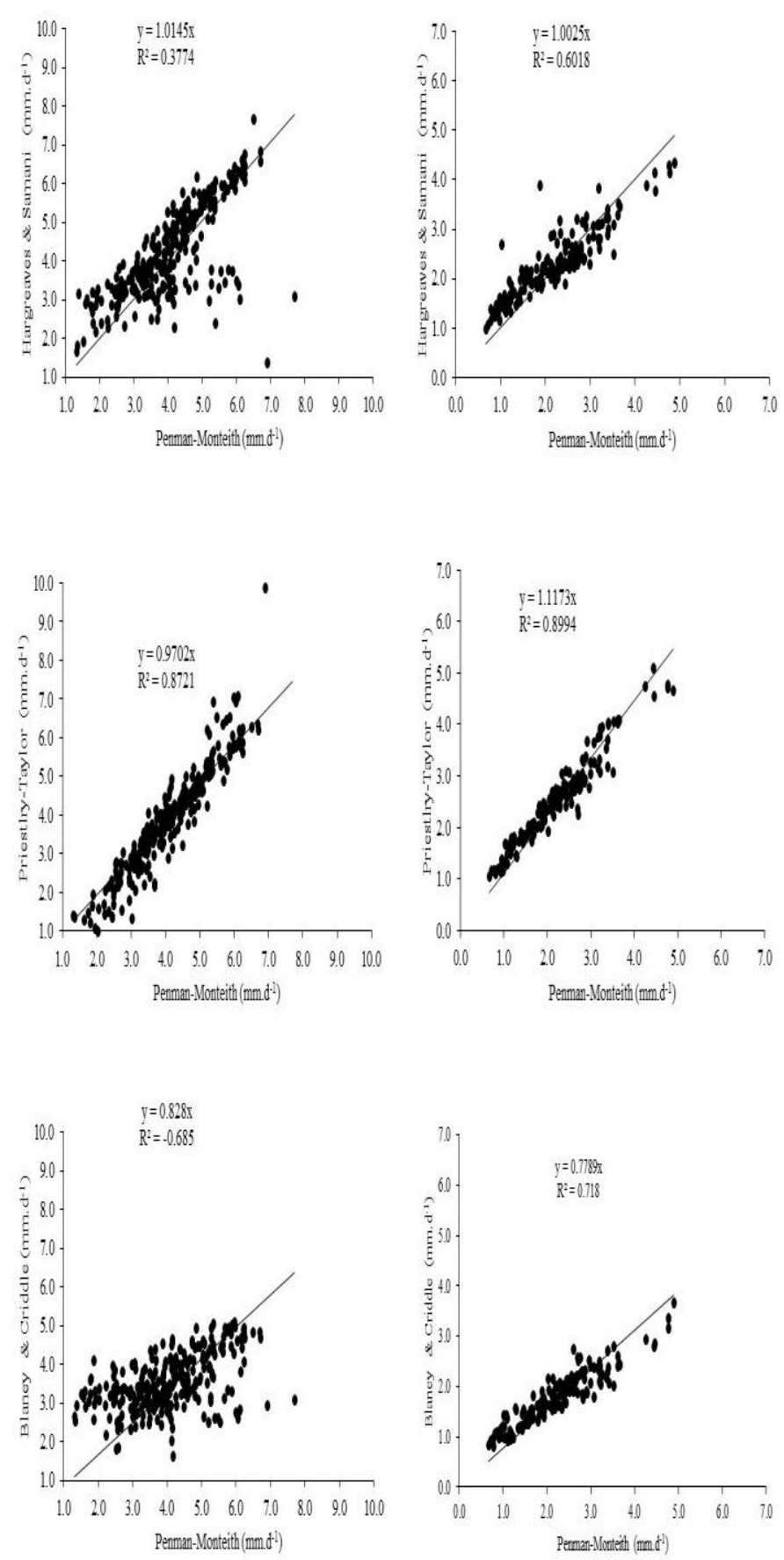

Figure 2. Equation parameters $(\beta 0, \beta 1)$, coefficient of determination $\left(\mathrm{R}^{2}\right)$, standard error of estimate (SEE), standard error of adjusted estimate (EPEA), correlation coefficient (r), index of agreement (d), the confidence index performance or (c), during the dry period in the two study sites. 
However, Oliveira et al. (2010) found in the northern region of Bahia that the methods of Hargreaves \& Samani and Makkink, which use as an input variable the air temperature and global solar radiation, showed good performance, both with coefficient "c" $=0.76$, similar results were found in this work for the method of Hargreaves \& Samani for both locations, which is important since the two regions are formed primarily by family farms, making it a simple and easy method to use by the local farming, so making more easy proper crop management, which are important in this region.

For all the statistical criteria used for Chagas et al. (2013) the methods of Penman 63, corrected FAO-Penman, FAO-Radiation and FAO-Blaney-Criddle showed the best assessment when compared with the PenmanMonteith in both evaluation periods. The method of Hargreaves \& Samani obtained lower classification than the other methods for estimate of ETo in the dry season and the humid season of the year in the city of Rio Real-BA, a result that differs from that found in this work, with this simple and easy application method, because it requires only data of maximum temperature, minimum temperature and site altitude. What further reinforces the use of this method to estimate reference evapotranspiration, given that agriculture in this region is family-based, thus requiring producers of simple methods for making the decision of when and how much to irrigate.

\section{CONCLUSION}

In the comparison of methods in the period analyzed the methods of Hargreaves \& Samani and Priestley-Taylor had the best performance, for both locations and periods evaluated being possible to indicate it to be used in the cities of Nova Venecia-ES and Santa Teresa-ES.

The method of Blaney \& Criddle also showed good performance being possible to indicate to be used in both locations studied, except in the dry period of Nova Venecia-ES.

\section{REFERENCES BIBLIOGRAPHIC}

ALLEN, R. G. et al. Guidelines for computing crop water requeriments. Rome: FAO, 1998. 308 p. (FAO Irrigation and Drainage, 56).

ALLEN, R. G.; PRUITT, W. O. Rational use of the FAO Blaney-Criddle formula. Journal of Irrigation and Drainage ASCE, New York, v. 112(IR2), p. 139-155, 1986.

ARAÚJO, W. F.; CONCEIÇÃO, M. A. F.; VENANCIO, J. B. Evapotranspiração de referência diária Em Boa Vista (RR) com base na temperatura do ar. Irriga, Botucatu, Edição Especial, p. 155 - 169, 2012.

BORGES JUNIOR, J. C. F.; ANJOS, R. J.; SILVA, T. J. A.; LIMA, J. R. S.; ANDRADE, C. L. T. Métodos de estimativa da evapotranspiração de referencia diária para a microrregião de Garanhuns, PE. Revista Brasileira de Engenharia Agrícola e 
Ambiental, Campina Grande, v.16, n.4, p.380 390, 2012.

BUSATO, C. C. M.; BUSATO, C. Evapotranspiração da videira em Santa Teresa, ES: coeficiente de cultura "único" padrão boletim FAO 56. Revista Verde de Agroecologia e Desenvolvimento Sustentável, Mossoró, v.6, n.4, p.251-257, 2011.

BRAGANÇA, B.; REIS, E. F.; GARCIA, G. O. PEZZOPANE; J. E. M. Estudo comparativo da estimativa da evapotranspiração de referência no período chuvoso para três localidades no Estado do Espírito Santo. Idesia, Chile, v. 28, n.2, p.21-29, 2010.

CAMARGO, A. P.; SENTELHAS, P. C. Avaliação do desempenho de diferentes métodos de estimativa da evapotranspiração potencial no estado de São Paulo. Revista Brasileira de Agrometeorologia, Santa Maria, v. 5, n. 1, p. 89-97, 1997.

CAMARGO, A. P. Balanço hídrico no estado de São Paulo. 3. ed. Campinas: IAC, 1971. 24 p. (Boletim, n.116).

CAVALCANTE JÚNIOR, E. G.; OLIVEIRA, A. D.; ALMEIDA, B. M.; SOBRINHO, J. E. Métodos de estimativa da evapotranspiração de referência para as condições do semiárido Nordestino. Semina: Ciências Agrárias, Londrina, v. 32, suplemento 1, p. 1699-1708, 2011.

CHAGAS, R. M.; FACCIOLO, G. G.; NETTO, A. O. A.; SOUSA, I. F.; VASCO, A. N.; SILVA, M. G. Comparação entre métodos de estimativa da evapotranspiração de referência (ETo) no município de Rio Real-BA. Irriga, Botucatu, v.18, n.1, p.351-363, 2013.
FRANÇA NETO, A. C.; MANTOVANI, E. C.; VICENTE, M. R.; VIEIRA, G. H. S.; SEDIYAMA, G. C.; LEAL, B. G. Comparação entre métodos simplificados de estimativa da evapotranspiração de referência (ETo) para regiões produtoras de café brasileiras. Coffee Science, Lavras, v.6, n.2, p.159-171, 2011.

GARDIMAN JUNIOR, B. S.; MAGALHÃES, I. A. L.; CECILIO, R. A. Comparação entre diferentes métodos de estimativas de evapotranspiração de referência (ETo) para Linhares-ES. Nucleus, Ituverava, v.9, n.2. 2012.

GONÇALVES, F. M.; FEITOSA, H. O.; CARVALHO, C. M.; GOMES FILHO, R. R.; JÚNIOR, M. V. Comparação de métodos da estimativa da evapotranspiração de referência para o município de Sobral-CE. Revista Brasileira de Agricultura Irrigada, Fortaleza, v.3, n.2, p.71-77, 2009.

HARGREAVES, G. L.; SAMANI, Z. A. Reference crop evapotranspiration from temperature. Basin. Journal of the Irrigation and Drainage Division-ASCE, New York, v. 111, n. 1, p. 113-124. 1985.

INCAPER - Instituto Capixaba de Pesquisa, Assistência Técnica e Extensão Rural. Planejamento e Programação de ações (2011), Nova Venécia e Santa Teresa-ES, p.27, 2011.

JENSEN, M. E.; BURMAN, R. D.; ALLEN, R. G. Evapotranspiration and irrigation water requeriments. New York: ASCE, 1990. 332 p.

MAKKINK, G.F. Testing the Penman formula by means of lysimeters. Journal of the Institution of Water Engineers, New York, v. 11, n.2, p. 277-288, 1957. 
OLIVEIRA, G. M.; LEITÃO, M. M. V. B. R.; BISPO, R. C.; SANTOS, I. M. S.; ALMEIDA, A. C. Comparação entre métodos de estimativa da evapotranspiração de referência na região norte da Bahia. Revista Brasileira de Agricultura Irrigada, Fortaleza, v. 4, n. 2, p. 104-109, 2010.

PRIESTLEY, C. H. B.; TAYLOR, R. J. On the assessment of surface heat flux and evaporation using large scale parameters. Monthly Weather Rev., Boston, v. 100, n. 2, p. 81-92, 1972.

REIS, E. F.; BRAGANÇA, R.; GARCIA, G. O.; PEZZOPANE, J. E. M.; TAGLIAFERRE, C. Estudo comparativo da estimativa da evapotranspiração de referência para três localidades do estado do espírito santo no período seco. Idesia, Chile, v.25, n.3, p.75-84, 2007.

RODRIGUES, R. R.; PIZETTA, S. C.; REIS, E. F.; RIBEIRO, W. R.; CAPELINI, V. A. Estimativa da demanda hídrica do cafeeiro Conilon, variedade Robusta Tropical, em comparação com a evapotranspiração obtida pelo método de Hargreaves \& Samani. Enciclopédia Biosfera, Goiânia, v.9, n.16, p.1055-1066, 2013.

SANTOS, W. O.; BATISTA, B. D. O.; ASSIS, J. P.; RODRIGUES, W. M.; SOBRINHO, J. E.
Métodos de estimativa da evapotranspiração de referência (ETo) para a região de Mossoró-RN. Revista Verde, Mossoró, v.5, n.5, p. 210 221,2010.

SILVA, V. J. ; CARVALHO, H. de P.; SILVA, C. R. da; CAMARGO, R. de; TEODORO, R. E. F. Desempenho de diferentes métodos de estimativa da evapotranspiração de referencia diária em Uberlândia, MG. Bioscience Journal, Uberlândia, v.27, n.1, p.95-101, 2011.

SOUZA, A. P. de; CARVALHO, D. F. de; SILVA, L. B. D. da; ALMEIDA, F. T. de; ROCHA, H. S. da. Estimativas da evapotranspiração de referencia em diferentes condições de nebulosidade. Pesquisa Agropecuária Brasileira, Brasília, v.46, n.3, p.219-228, $2011 b$.

SOUZA, L. P. de; FARIAS, O. S.; MOREIRA, J. G. V.; GOMES, F. A.; JUNIOR, E. F. F. Comparação de métodos da estimativa da evapotranspiração de referencia para o município de Cruzeiro do Sul - Acre. Enciclopédia biosfera, Goiânia, vol.7, n.12;p. 1-8, 2011a.

WILLMOTT, C. J.; CKLESON, S. G.; DAVIS, R. E. Statistics for evaluation and comparison of models. Journal of Geophysical Research, Ottawa, v. 90, n. 5. p. 8995-9005. 1985. 